\title{
LAW ENFORCEMENT OF MONEY LAUNDERING IN BANKING
}

\author{
Afif Muhni \\ Master Programme Law student, Post Graduate School of Law \\ Hasanuddin University \\ South Sulawesi, Indonesia \\ Andi Sofyan \\ Professor of Law, Post Graduate School of Law \\ Hasanuddin University \\ South Sulawesi, Indonesia \\ Andi Tenri Famauri \\ Ph.D of Law, Post Graduate School of Law \\ Hasanuddin University \\ South Sulawesi, Indonesia \\ Muhammad Basri \\ Ph.D of Law, Post Graduate School of Law \\ Hasanuddin University \\ South Sulawesi, Indonesia \\ DOI: 10.31364/SCIRJ/v8.i1.2020.P0120741 \\ http://dx.doi.org/10.31364/SCIRJ/v8.i1.2020.P0120741
}

\begin{abstract}
This study aims to identify the mechanism of money laundering in banking institutions in Indonesia. This type of research is a legal research of the juridical-sociological approach. The location of the study was conducted at several banks including Bank Niaga, Bank Cental Bank Asia and Bank Indonesia (BI) in Makassar City. Legal materials used to solve problems as formulated in this legal research are sourced from primary, secondary and tertiary legal materials. Data obtained through data collection in the form of interviews and literature study. The data obtained both primary and secondary data, were analyzed qualitatively. The results showed that the mechanism of eradicating money laundering at banking institutions in Indonesia has been regulated by UndangUndang Nomor 8 Tahun 2010 concerning Prevention and Eradication of Money Laundering. Money laundering regulations are considered effective in anticipating and eradicating money laundering by tracking the flow of funds in banking institutions related to disclosure of crimes seized at the same time also criminalizing anyone who receives a flow of crime. This authority is exercised by the PPATK (Financial Transaction Reports and Analysis Center), which has the task of preventing and combating money laundering.
\end{abstract}

Index Terms - crime, money laundering, banking and PPATK

\section{INTRODUCTION}

Authority in law enforcement and activities has been regulated and controlled to the maximum by the government. In limiting the government's authority to run the law in society in general and specifically to the perpetrators of crimes and the imposition of sanctions, so that criminal law is present as a collection of rules governing and determining all acts that are prohibited from doing as well as sanctions (Material Law), and how the maker will be subject to sanctions in accordance with the provisions regulated or called formal law. The development of Criminal Law along with the development of aspects in people's lives that lead to actions violating legal norms. The development of economic needs and financial transactions triggered the crime of money laundering. This criminal act is called a special criminal act or a criminal offense regulated outside the Criminal Code (KUHP) with its own provisions of the Criminal Procedure Code (KUHAP) ${ }^{[1]}{ }^{[2]}$.

The development of the Criminal Procedure Code has been regulated separately based on several new provisions or deviates from the General Criminal Procedure Code. In addition to the Money Laundering Crime there are also several other special criminal offenses that were born after the establishment of the Indonesian Penal Code. Some of these crimes are also related to Money 
Laundering in terms of the causes of the occurrence of these criminal acts. Money Loundrying Crime is an attempt to conceal or disguise the origin of money or assets resulting from criminal acts through various financial transactions so that the money looks as if it comes from a legal activity. In recent years the problem of money laundering crimes has received attention from various groups because it has become more prevalent from time to time, not only on a national but also regional, even international scale. Money laundering crimes are usually committed by individuals or corporations, which are aspects of criminality with individuals, nations and countries $^{[3][4][5]}$.

The practice of money laundering crimes can be carried out by someone without having to travel out of town or abroad, with technological advances through cyberspace by utilizing internet facilities, then a money laundering crime perpetrator can deposit dirty money to a particular bank without having to include biodata or identification information electronically. This money laundering crime is a transnational organized crime, so that its eradication is often related to the jurisdiction of other countries, and requires international cooperation. In connection with cooperation in eradicating money laundering, the Indonesian state with several other countries have collaborated with government agencies namely The Asia Pacific Group on Money Laundering and The Financial Action Task Force ${ }^{[6]}$.

Indonesia is said to be a country that is rife with smuggling of illegal goods because it is considered weak law enforcement. Initially in the international world money laundering crimes related to drug trafficking / narcotics and other major crimes and not associated with crimes such as corruption, but now money laundering has been associated with the process or money from criminal acts which are generally large amounts, while in various countries including Indonesia, the money obtained from the results of corruption are included in the criminal category, so the money laundering case is associated with a corruption case. The practice of money laundering in Indonesia can also be caused by Indonesia adopting a free foreign exchange system. The free foreign exchange system allows anyone to freely enter or hold foreign exchange out of Indonesia's jurisdiction ${ }^{[7]}$.

Foreign exchange is intended to overcome the limited funds for national development, this invites the entry of foreign investors to invest their capital in Indonesia, but on the other hand there is an unwanted impact in the form of negative effects of money laundering. This free foreign exchange system also allows for various techniques of money laundering through cross-country transactions and is difficult to trace, whereas domestic corruptors also find it easier to transfer illegal funds to be washed through foreign banks, in addition to the many capital market investments and foreign exchange businesses that enliven the practice of money laundering. The emergence of an electronic banking technology system commonly referred to as Electronic Money or E-money.

Electronic Money System is a system that is digitally signed by the issuing institution through a private encryption key and can be transmitted to other parties in secret. E-money deals with the internet cyber payment system which is then used by money launderers. The bank secrecy system adopted by a country is also one of the factors for money laundering, the tighter a country's banking secrecy is, the more intense it is used as a means for money laundering. This study aims to identify the mechanism of money laundering in banking institutions in Indonesia.

\section{LITERATURE REVIEW}

Conceptually, the essence and meaning of law enforcement lies in the activity of harmonizing the relationships of values that are set out in the rules that embody and act as a series of translation of the final stage of values, to create, preserve and maintain peaceful life relationships. These rules then become guidelines or benchmarks or attitudes that are considered appropriate, or should be. The behavior or attitude of the action aims to create, maintain and maintain peace. Thus the concretization of the concept of law enforcement. Law enforcement as a process, in essence is the application of discretion that involves making decisions that are not strictly governed by the rule of law, but has an element of personal judgment. Interference with law enforcement may occur, if there is a discrepancy between the value of the rules and patterns of behavior. The disturbance occurs, if the discrepancy between the values that are paired, incarnate in the rules that are muddled, and patterns of undirected behavior that disrupt the peace of life ${ }^{[8]}$.

Law enforcement is an effort to bring the ideas of justice, legal certainty and social benefits into reality. Law enforcement is the process of creating ideas. Law enforcement can be divided into [9]: (a) preventive; (b) repressive; and (c) curative. Law enforcement is the process of carrying out efforts or the actual functioning of legal norms as guidelines for actors in traffic or legal relations in the life of society and the state. Law enforcement is an effort to realize legal ideas and concepts that people expect to become reality. Law enforcement is a process that involves many things.

Law enforcement is the activity of harmonizing the relationships of values that are spelled out in the rules / views of steady and manifest values and actions as a series of translation of the final stages of value to create, maintain and maintain peaceful life relationships. ${ }^{[10]}$. Concrete law enforcement is positive law enforcement in practice as it should be obeyed. Therefore, giving justice in a case means deciding the law in concreto in maintaining and guaranteeing compliance with material law using procedural methods determined by formal law. Law enforcement is essentially the enforcement of ideas or concepts about justice, truth, social benefits, and so on ${ }^{[11]}$. Essentially law enforcement embodies the values or methods that contain justice and truth, law enforcement is not only the duty of conventional law enforcers, but it is the duty of everyone. Nevertheless, in relation to public law the government is responsible.

Law enforcement can be divided into two, namely: in terms of (a) the subject's angle: in a broad sense, the process of law enforcement involves all legal subjects in every legal relationship. Anyone who runs a normative rule or does something or does not 
do something by basing himself on the norms of the rule of law, means that he runs or enforces the rule of law. In a narrow sense, law enforcement is only interpreted as an effort by certain law enforcement officers to guarantee and ensure that a rule of law runs as it should. In terms of (b) the angle of the object, namely in terms of the law: in the broadest sense, law enforcement which includes the values of justice which contains the sound of formal rules and values of justice that exist in society. In the narrow sense, law enforcement only involves formal and written enforcement of regulations ${ }^{[2]}$.

Law Enforcement Theory is an attempt to bring the ideas of justice, legal certainty and social benefits into reality. So law enforcement is essentially the process of embodying ideas. Law enforcement is the process of carrying out efforts or the actual functioning of legal norms as guidelines for actors in traffic or legal relations in the life of society and the state. Law enforcement is an effort to realize legal ideas and concepts that people expect to become reality. Law enforcement is a process that involves many things namely the scope of criminal law enforcement as formulated by the subtantive law of crime ${ }^{[12]}$.

This total criminal law enforcement is not possible because law enforcers are strictly limited by criminal procedural law which includes rules for arrest, detention, search, confiscation and preliminary examination. In addition, there may be substantive criminal law itself that provides restrictions. For example, complaints are needed first as a condition for prosecution in offenses for complaints (klacht delicten). This limited scope is called the area of no enforcement. Full enforcement, after the total scope of criminal law enforcement is reduced the area of no enforcement in law enforcement, law enforcement is expected to maximum law enforcement. Actual enforcement, full enforcement is considered not a realistic expectation, because of the limited limitations in the form of time, personnel, investigation tools, funds and so on, all resulting in the necessity of discretion and the rest is what is called actual enforcement.

Criminal law enforcement is divided into three parts namely: total enforcement application, involving structural sub-systems consisting of the police, prosecutors, courts and the community, including legal advisory institutions. The application of law is seen from three main dimensions, namely: (a) the application of law as a normative system is the application of all legal rules that describe social values and are supported by various criminal sanctions; (b) the application of law as an administrative system includes interactions between law enforcement officials who are part of the justice sub-system; and (c) the application of criminal law is a social system, so that criminal acts must be taken into account perspectives owned by various levels of society.

Factors that influence the effectiveness of law enforcement ${ }^{[10]}$ are explained as follows (a) legal factors, the factual practice of law enforcement there are times when there is a conflict between legal certainty and justice, this is caused by the conception of justice is an abstract formula, whereas legal certainty is a procedure that has been determined normatively. A policy or action that is not entirely based on law is something that can be justified as long as the policy or action is not contrary to law. So in essence the administration of law does not only include law enforcement, but also peace maintenance, because the implementation of law is actually a process of harmonizing between the value of the method and the pattern of real behavior aimed at achieving peace.

The next factor is (b) law enforcement, legal function, mentality or personality of law enforcement officers play an important role, if the rules are good, but the quality of officers is not good, problems will arise. Therefore, one of the keys to success in law enforcement is the mentality or personality of law enforcement. Next factor (c) Supporting facility or facility factor. Factors supporting facilities or facilities include software and hardware, one example of software is education. Education received by the police today tends to be conventional practical matters, so that in many cases the police experience obstacles in their objectives, including knowledge of computer crime, in specific criminal acts which have so far been given authority to prosecutors, this is because technically the police are considered unable and not ready. Although it is also realized that the tasks that must be carried out by the police are so broad and numerous ${ }^{[13]}$.

The next factor is (d) the factor of law enforcement society comes from the community and aims to achieve peace in the community. Every citizen or group has more or less legal awareness, the problem that arises is the level of legal compliance, namely high, moderate, or lacking legal compliance. The degree of community legal compliance with the law, is one indicator of the functioning of the law in question. The last factor (e) cultural factor. Based on the concept of everyday culture, people often talk about culture. Culture has a very big function for humans and society, namely regulating so that humans can understand how they should act, act, and determine their attitudes when they relate to others. Thus, culture is a basic outline of behavior that sets rules about what must be done, and what is prohibited ${ }^{[14]}$.

\section{RESEARCH METHODS}

This type of research is a legal research that uses a type of sociological juridical that is by studying or analyzing secondary data in the form of secondary legal materials by understanding the law as a set of rules or positive norms in the legal system that governs people's lives. The location of the study was conducted at several banks including Bank Niaga, Bank Cental Asia Bank and Bank Indonesia (BI) in the Makassar City area, the basis of consideration of the Bank having a branch office in Makasssar and also having a regional office in Makassar. This type of research used is a sociological juridical method meaning a study conducted on real conditions in the community or community environment with the intent and purpose of finding facts that then lead to identification and ultimately to the problem solution.

Legal materials used to solve problems in this legal research are sourced from primary, secondary and tertiary legal materials. Literature Study, the data collection stage is carried out through a literature study that is collecting data based on references from literature books various legislation or literature relating to research issues namely regarding money laundering and materials

WwW.scirj.org

(C) 2020, Scientific Research Journal

http://dx.doi.org/10.31364/SCIRJ/v8.i1.2020.P0120741 
related to money laundering cases to obtain legal material. Field Study which is as a support for the literature data mentioned above, so in the field research the legal research conducted is to make an inventory of legal facts, and eliminate things that are not relevant to determine the legal issues to be solved.

This research is a sociological juridical research, as an effort to obtain objective data, this research uses data obtained through data collection in accordance with the approach method: (a) Interview, namely conducting in-depth question and answer by using interview guidelines previously prepared; and (b) Literature Study, which is recording data directly from material documents that have binding power such as basic norms and legislation related to this research, namely the Criminal Code and Law No. 8 of 2010, concerning the Prevention and Eradication of Money Laundering Crimes as well as other laws and regulations.

\section{RESULTS AND DISCUSSION}

Avoiding things that can harm the bank and the customer, the bank issues special provisions. The law governing banking problems called banking law is a set of positive legal provisions that apply either in the form of laws and regulations, or jurisprudence, or doctrines that govern bank matters as an institution, and aspects of operational activities, rules that must be met by a bank, behavior employees, rights, obligations, duties and responsibilities of all parties related to banking activities, things that may or may not be done by the bank, the existence of banks, and others related to banking.

As for what constitutes the scope of banking legal arrangements are as follows: (a) banking principles, such as the norms of efficiency, effectiveness, bank health, professionalism of banking agents, the aims and objectives of banking institutions, relationships, rights and obligations of banks; (b) banking actors, such as board of commissioners, directors and employees, as well as affiliated parties. Regarding the form of legal entity management, such as Persero, Regional Companies, cooperatives or limited liability companies. Regarding forms of ownership, such as government, private sector, joint ventures with foreign or foreign banks; (c) banking principles specifically intended to regulate the protection of public interests from banking actions, such as preventing unfair competition, anti-trust, customer protection, and others; and (d) concerns the organizational structure related to the banking sector, such as the existence of the Monetary Board, the Central Bank, etc. That leads to securing the objectives to be achieved by the bank's business, such as courts, sanctions, incentives, supervision, prudent banking, and others.

The laws and regulations in the banking sector are arranged as a system bound by certain legal principles. Positive law (banking) comes from written and unwritten provisions. Written provision is a provision established by an authorized legal and legislative body, be it in the form of original regulations or derivative regulations; whereas unwritten provisions are provisions that arise and are maintained in the practice of conducting banking operations. The provisions of banking law govern the institutional management of banks. It stipulates the requirements for establishing a bank, which includes licensing, legal form, management, and bank ownership. Also regulates the building of organizations that support banking business activities, also includes provisions on the guidance and supervision of banks by Bank Indonesia and bank secrecy.

The provisions of banking law also regulates aspects of its business activities. One of the main functions of banks is the collection of public funds and channeling them. These activities are realized in the form of deposits and others. Then the funds raised are channeled back in the form of lending or financing based on sharia principles and other bank ventures. In addition, banks conduct business in providing banking services that are not included in their main function. The Banking Act was amended, the bank can also carry out other activities that are commonly carried out by banks, as long as these other activities are not in conflict with applicable laws and regulations. Sources of banking law banking law is the law that regulates everything related to banks, both institutional, business activities and the ways and processes in carrying out bank business. Contains legal regulations (legal norms), and legal principles, legal structure, and legal culture that regulates everything related to banks. Bank legal sources can be divided into several sources of legal both formal and material legal sources. Formal legal sources are the places where the legal provisions and (written) laws governing banking are explained. The source of material law is the source of law that determines the substance of the law, and depends on where the review is conducted, whether from an economic, historical, sociological, and other point of view. The source of material law will be considered if deemed necessary to know the origin of the law.

Specific rules governing or banking can be identified in: (a) Act Number 7 of 1992 concerning banking which has been amended by Act Number 10 of 1998; (b) Act Number 23 of 1999 concerning Bank Indonesia; Law Number 24 of 1999 concerning Foreign Exchange Flows and the Exchange Rate System; (c) Burgerlijk Wetboek (Civil Code), especially the provisions of Books II and Book III concerning guarantee and agreement law; (d) Wetboek van Koopenhandel (Book of Commercial Law), especially the provisions of Book I concerning securities; (e) Faillissement Verordening has been amended with Government Regulation in Lieu of Law Number 1 of 1998 ratified into Law with Law Number 4 of 1998; (f) Law Number 5 of 1962 concerning Regional Enterprises; Law Number 25 of 1992 concerning Cooperatives; (g) Law Number 7 of 1994 concerning Ratification of the Agreement on Estabilishing of the World Trade Organization; (h) Act Number 1 of 1995 concerning Limited Liability Companies; (i) Law Number 8 of 1995 concerning Capital Markets; (j) Law Number 9 of 1995 concerning Small Businesses; (k) Law Number 4 of 1996 concerning Mortgage Rights and Land Related Items.

There are other factors that help the formation of banking law, including agreements made between banks and customers; legal teachings through the judiciary contained in the judge's decision (jurisprudence); legal doctrines; and habits and custom that apply in the banking world. The nature of Indonesian banking law has a compelling nature, meaning that banks in carrying out their business must comply and comply with the rules stipulated in the law. If the banking regulations are violated, Bank Indonesia has the

WWW.scirj.org

(C) 2020, Scientific Research Journal

http://dx.doi.org/10.31364/SCIRJ/v8.i1.2020.P0120741 
authority to act against the bank concerned by imposing administrative sanctions, such as revoking its business license. However, in the context of internal supervision, banks are allowed to make their own internal regulations (self regulation) based on general policies determined by Bank Indonesia. The bank's own internal provisions are intended as a standard or clear and strict standard in bank internal supervision, so that the bank is expected to be able to carry out its own policies properly and responsibly.

Bank secrecy has the potential as a safe haven for depositing money, so for the purpose of auditing in cases of money laundering, investigators, public prosecutors or judges authorized to request information from financial service providers regarding the assets of everyone reported by PPATK. Pursuant to Article 38 of Law No. 8 of 2010 concerning Prevention and Eradication of Money Laundering (PP-TPPU), PPATK has the duty to prevent and eradicate money laundering.

The PPATK Institute was initially known in Indonesia in Act Number 15 of 2002 concerning Money Laundering Acts which was published on April 17, 2002. On October 13, 2003, the Regulation was amended or replaced by Law No. 25 of 2003 concerning Amendments to Law No. 15 of 2002 concerning Criminal Acts of Money Laundering. In an effort to provide a strong legal basis to prevent and eradicate money laundering, then on October 22, 2010 Law No. 8 of 2010 concerning Prevention and Eradication of Money Laundering Acts that replaces the previous law.

One of the most important things is the determination of the legal basis for the formation of an institution called the PPATK. This PPATK is needed to deal with illegal efforts in money laundering practices. This becomes important because the problems of money laundering crimes are quite heavy, complex and regional to international scale. Basically the tasks and functions of PPATK are Financial Intelligence and in the handling of anti-money laundering in some countries it is called the Financial Intelligence Unit (FIU). Not all countries have institutions whose tasks and functions are the same, and each country has a different style and authority, according to the administration system of each government. The role of the PPATK in handling or processing a money laundering crime that occurred in Indonesia is very complex, seen in the Panama Papers case which contains information on the network of powerful and rich people in the world who use tax relief policies (tax havens) to hide wealth, launder money, or avoid taxes one of which is the State of Indonesia included in the case.

\section{CONCLUDING REMARKS}

PPATK has the duty to carry out examination and investigation of reports and information on financial transactions that have an indication of a crime of money laundering. The mechanism for eradicating money laundering is under the authority of PPATK, so that if PPATK does not carry out its functions effectively it is difficult to realize the implementation of regulations on money laundering in Indonesia. The role of the PPATK in handling a money laundering crime in Indonesia is so complex based on large cases that occur. For depositing money, for the purposes of examination in money laundering cases, investigators, public prosecutors or judges are authorized to request information from financial service providers regarding the assets of every person that has been reported by PPATK.

\section{REFERENCES}

[1] Hamzah, A. (2008) Hukum Acara Pidana Indonesia, Jakarta : Sinar Grafika

[2] Hartono. (2010) Penyidikan dan Penegakan Hukum Pidana Melalui Pendekatan Progresif, Jakarta ; Sinar Grafika

[3] Amirullah, A. (2003) Money Laundering Tindak Pidana Pencucian Uang. Bayu Media Publishing : Malang

[4] Yustiavandana, Ivan dkk. (2010) Tindak Pidana Pencucian Uang Di Pasar Modal. Ghalia Indonesia: Bogor

[5] Djaja, E. (2010) Memberantas Korupsi Bersama KPK, Sinar Grafika: Jakarta

[6] Sjahdeini, Sutan Remy. (2007) Seluk Beluk Tindak Pidana Pencucian Uang dan Pembiayaan Terorisme. Pustaka Utama Graffiti: Jakarta

[7] Sutedi, A. (2007) Hukum Perbankan, Suatu Tinjauan Pencucian Uang, Merger, Likuidasi dan Kepailitan. Sinar grafika: Jakarta

[8] Chazawi, A. (2002) Pelajaran Hukum Pidana. Jakarta: Raja Grafindo Persada

[9] Sudarto. (1983) Hukum Pidana dan Perkembangan Masyarakat, Sinar Baru, Bandung

[10] Soekanto, S. (2004) Faktor faktor yang mempengaruhi Penegakan Hukum, Raja Grafindo Persada, Jakarta

[11] Raharjo, S. (1987) Masalah Penegakan Hukum, Sinar Baru, Bandung

[12] Soekanto, S. (2008) Faktor-Faktor yang Mempengaruhi Penegakan Hukum. Jakarta: Raja Grafindo

[13] Arief, Barda Nawawi. (2014). Kebijakan Hukum Pidana, Kencana Prenada Media Group, Semarang

[14] Sabian, Utsman. (2008) Menuju Penegakan Resenponsif. Yogyakarta: Pustaka Pelajar 